disentanglement of the backlog of family partnership disputes, a result effected by encouraging settlement of pending disputes and by discouraging appeals and reversals. ${ }^{48}$

\title{
SUCCESSION TO TRUSTEESHIP UPON CONSOLIDATION OR MERGER OF CORPORATE FIDUCIARY
}

While in most jurisdictions all rights and obligations of consolidating or merging corporations are automatically transferred to the resulting corporation, some states condition succession to trusteeships upon court approval. ${ }^{2}$ This requirement stems from the rule against delegating trusteeships, the emerging corporation being considered a legal entity different from the appointed trustee. ${ }^{2}$ The requirement is said to be justified by the reliance of a settlor on the trustee's personal interest in the beneficiaries, business judgment, and financial responsibility. Although sound when applied to natural trustees, such reasoning seems inappropriate when the trustee is a corporation. ${ }^{3}$ The size and activity of corporate trustees belie the notion that there is anything personal about their administration of trusts. ${ }^{4}$ As for faith in business judgment, limitations imposed by statute and judicial standards of prudence leave little scope

${ }^{4}$ Since the Culbertson case makes the ultimate issue one of intent, necessarily a finding of fact, it could be argued that the decision provides few grounds upon which an appellate court could reverse a Tax Court decision. However, the appellate courts accepted the Tax Court interpretation of the Tower case, and it would seem that only findings of fact were involved prior to the Culbertson case; hence perhaps no improvement can be expected. At least it can be hoped that more respect will be given to Tax Court findings in view of the finality which the Supreme Court indicated should be accorded them.

I Unless, of course, the trust instrument provides otherwise. Generally, consult 3 Bogert, Trusts and Trustees $\S 53 \mathrm{I}$ (rev. ed. I946); Fruchtman, The Effect of Merger or Consolidation on the Succession of Corporate Trustees, 22 Ky. L. J. 378 (I934); Bogert, Some Recent Developments in the Law of Trusts, 23 IIl. L. Rev. 749, 757-65 (I929). Twenty states have statutes explicitly providing for automatic succession to fiduciary relationships by the resulting corporation. 3 Bogert, op. cit. supra at $325 \mathrm{n}$. 15 . The court approval requirement is the result of judicial limitation of consolidation statutes providing in general terms for automatic transfer of rights and obligations. Compare Stevens v. First Nat. Bank, x73 Ga. 332, 160 S.E. 243 (r93I); Hofheimer v. Seaboard Cit. Nat. Bank, $x_{54}$ Va. 392, $x_{53}$ S.E. 656 (r930); Commonwealth-Atlantic Nat. Bank of Boston, petitioner, 249 Mass. 440, I44 N.E. 443 (I924). For an exhaustive tabulation and analysis of state statutes, see Fruchtman, op. cit. supra at 389-99. It is now standard practice to provide in the trust instrument for automatic succession by the resulting corporation in the event of consolidation or merger. 3 Bogert, op. cit. supra at $325 ; x$ Scott on Trusts $\$ 96.7$ (1939).

2 Cases cited note I supra; 3 Bogert, Trusts and Trustees $\S 531$ at 322-25 (rev. ed. r946).

3 See First Nat. Bank of Chattanooga v. Harry E. Chapman Co., x60 Tenn. 72, 22 S.W. 2d 245 (I929); Chicago Title \& Trust Co. v. Zinser, 264 IIl. 3I, 105 N.E. 718 (I914); In re Bergdorf's Will, 206 N.Y. 309, 99 N.E. 7I4 (I912). But see Fruchtman, op. cit. supra note I, at 394-96; Bogert, Some Recent Developments in the Law of Trusts, 23 Ill. L. Rev. 749, 765 (xg29).

4 In I947, 2,976 American companies controlled $\$ 36,162,16 \mathrm{x}, 448$ of personal trust property, the average being about \$I million per company. Stephenson, Trust Business in the United States, I947, 86 Trusts \& Estates 206 ( I948). See Institutionalized Trusteeship, 58 Yale L. J. 924 ( 1949$)$. 
for genuine discretionary activity. ${ }^{5}$ And the supervisory powers exercised by the Comptroller of the Currency over national banks; and by the Federal Deposit Insurance Corporation, the federal reserve banks, and state agencies over state banking and trust institutions, provide a more effective safeguard for trust funds than any private or judicial appraisal could be expected to achieve. ${ }^{6}$ Finally, a settlor's choice of trustee based on the small differences which do exist between available corporations can be nullified by changes in trustee policy or personnel which do not affect the corporate entity. 7

In those situations where the merger or consolidation is merely a paper transaction, and the actual organizational machinery which has been administering the trust remains unchanged, the settlor's judgment in choosing a trustee would be positively disregarded were the trusteeship diverted from the new or surviving corporation. However, no court applying the rule against automatic succession has made an exception in such a case.

Many of these transactions have taken place as a result of the changing relationship of national banks to the trust business. Because the administration of trusts was not an important adjunct of the banking business when the $\mathrm{Na}$ tional Banking Act ${ }^{8}$ was passed in 1864 , no authority was given national banks to become trustees. Subsequently they found this lack of authority a handicap in their competition with trust companies, which were expanding into the general banking field.9 Some national banks overcame the disability by setting up trust affiliates incorporated under state law. ${ }^{x 0}$ Although the Federal Reserve

$s$ Some statutes limit trust investments to those specified unless broader powers are given by the trust instrument. Where the statutory list is merely advisory, unlisted investments are not unauthorized per se, but the dangers of malfeasance suits for losses on investments render very attractive the presumption of soundness which attaches to "legal" investments. Other statutes merely restate the common-law standard of the reasonable and prudent trustee. See Legal Lists in Trust Investment, 49 Yale L. J. 89I (I940); Standards of Care for Corporate Trustees, I6 Univ. Chi. L. Rev. 579 (I949).

${ }^{6} 4$ Bogert, Trusts \& Trustees $\$ 980$ (rev. ed. 1946 ). While the primary purpose of supervision and examination is to discover dangers to the solvency of the institution, trust department procedure and accounts are also investigated for violations of regulations governing investment policy, accounting methods, segregation of trust assets, and self-dealing. Periodical inspections supplement the one made when the corporation is first granted power to accept trusts.

7 Even in the event of a merger, the trusteeships formerly held by the "surviving" corporation are not vacated, since its corporate entity continues. Yet the surviving corporation may have undergone quite as drastic a transformation as one whose corporate entity has been dissolved. 3 Bogert, Trusts \& Trustees $\$ 53$ I at 324 (rev. ed. 1946 ).

${ }^{8}{ }_{3}$ Stat. 99 (1864), as amended, 12 U.S.C.A. c. 2 (1945).

- See Smith, Development of Trust Companies in the United States 332-38, 345-5I (x928), for an analysis of the competition between the banks and the insurgent trust companies for general banking business between 1865 and I9II. Two main advantages enjoyed by the trust companies were freedom from reserve requirements and greater scope in making loans, particularly in the real estate field. Many states had qualified their banks as trustees, thereby further undermining the competitive position of national banks.

20 Herrick, Some Present Day Tendencies in 'Trust Company Management, 79 Bankers' Magazine (N.Y.) 350-52 (I909). 
Board has had authority since I9I3 to grant trusteeship powers to national banks, ${ }^{\text {II }}$ it was not until the McFadden Act ${ }^{12}$ of ${ }^{2} 927$ that the banks were allowed to consolidate or merge with their trust affliates. By this act Congress attempted to change corporate entity theory in consolidations involving national banks, by providing that the corporate existence of the constituent banks should be continued in the emerging corporation. Furthermore, the statute explicitly stated that the resulting company was to succeed automatically to all trusteeships held by the component institutions. However, because of the constitutional doctrine that the regulation of property in trust is a local matter, this provision was held to govern only where not contrary to state law..$^{13}$

This is the background to De Korwin o. First National Bank of Chicago, ${ }^{14}$ recently decided by the Court of Appeals for the Seventh Circuit. First National had acquired a trust department by incorporating the First Trust \& Savings Bank under Illinois law. In his will, Otto Young, an early director of First National, appointed the state affiliate to the trusteeship of his estate. After probate and acceptance of the trust, the trustee was consolidated with another Mlinois trust company, forming the First Union Trust \& Savings Bank. As had been the case with First Trust \& Savings Bank, the stock of the new company was owned by the shareholders and voted by the officers of First National. After the McFadden Act, First Union was consolidated with First National. The trust organization was in no way affected by these changes in its legal identity. From the time of the original appointment it has continued to administer the trust as a department of the First National Bank.

In a suit by the heirs of certain trust remaindermen, the district court decided that the succession to the trusteeship after the first consolidation was unauthorized, and held First National accountable from the date of the succession for all losses the trust fund had sustained and for all fees gained from its administration. ${ }^{25} \mathrm{Had}$ the court of appeals agreed that the succession was improper, it might still have questioned the liability imposed. The depression losses which formed the bulk of the damages were not caused by the failure to secure formal appointment, the only blameworthy conduct ascribed to the trustees $;^{16}$ nor did

II Federal Reserve Act of I9I3, $\S$ II (k), 38 Stat. 25I, 262 (I9I3), as amended, I2 U.S.C.A. $\S 248(\mathrm{k})$ (I945).

${ }^{12} 44$ Stat. $x 225$ (1927), as amended, I2 U.S.C.A. $\$ 34^{a}$ ( 1945 ).

${ }_{13}$ Ex parte Worcester Nat. Bank, 279 U.S. 347 (x929). Thirteen states have enacted statutes expressly providing for automatic succession to trusteeships in state-national consolidations. 3 Bogert, Trusts and Trustees $\$ 531$, at 327 n. 24 (rev. ed. 1946).

${ }^{14}$ I79 F. 2d 347 (C.A. 7 th, I949), reversing 84 F. Supp. 9 I8 (Ill., I949).

ss De Korwin v. First Nat. Bank of Chicago, 84 F. Supp. gr8 (Ill., r949).

${ }^{16}$ Compare Springfield Nat. Bank v. Couse, 288 Mass. 262, x92 N.E. 529 (I934), where an executor was not required to account $d e$ son torl for acts done as trustee before the overt act necessary to becoming legal trustee, namely, acceptance by the probate court of its accounts as executor. Compare Liability of Trustee in the Absence of Causal Relation between Wrongdoing and Loss, 5o Harv. L. Rev. 317 (1936). Failure to earmark trust securities as beld in 
this failure render the trustees' services any less valuable. ${ }^{17}$ However, the court of appeals found it unnecessary to consider this problem, for it decided that the trusteeship transfer was valid.

The first consolidation was effected under Section 12 of the Illinois Banking Act, ${ }^{18}$ which provides that "the rights of persons in any particular" shall not be affected by such a transaction. The only case applying this provision to a fiduciary relationship was Chicago Title $\&$ Trust Co. v. Zinser. ${ }^{\mathrm{x}}$ There a trust company which had been named executor in a will was consolidated prior to the death of the testator. The appointment of the resulting corporation as executor was upheld ${ }^{20}$ in a decision which permitted it to enforce specifically a contract to purchase estate property. The Illinois Supreme Court said:

The rule [that a trustee cannot delegate his authority] cannot be applied to the case of a corporation, because the element of trust in the judgment and discretion of an individual is entirely wanting.... Etta Nelson, in naming the Real Estate Title and Trust Company as executor and trustee, knew that its directors, officers, and stockholders might change from time to time, and that the statute authorized ... the consolidation of the corporation with any other corporation then existing or that might thereafter be organized. She therefore contemplated that these changes might occur.

The district court in De Korwin o. First National Bank distinguished the Zinser case on the facts, emphasizing the provision in Young's will for court appointment of a successor trustee with beneficiary approval "[i]n the event that said trustee [First Trust \& Savings Bank] shall refuse to qualify or act, or further act, as trustee under this will. ...." The court argued that the testator had meant this clause to govern in the event of consolidation. However, this does not seem a sufficiently clear expression of intent to warrant an exception to the general principle of automatic succession implied in the Zinser case. ${ }^{22}$

trust has not invariably resulted in liability for losses on them. Chapter House Circle of the King's Daughters v. Hartford Nat. Bank \& Trust Co., I2I Conn. 558, I86 Atl. 543 (1936).

${ }^{17}$ In Pease v. Kendall, 39 I Ill. I93, 63 N.E. $2 \mathrm{~d} 2$ (r945), a trustee de tort son (his appointment was void for lack of notice) was allowed fees for his services as trustee.

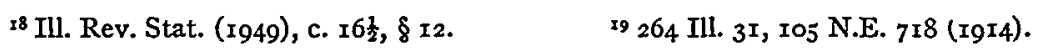

20 In the De Korwin case, the court of appeals argued that this decision, affirming the appointment of the consolidated corporation as executor rather than as administrator, stands for the proposition that a testator naming a corporate trustee also names all its successors by consolidation or merger. In support is Sartain v. Davis, 323 Ill. 269, 154 N.E. IOI (I926), which states that the probate court may appoint as executor only persons so designated in the will.

22 84 F. Supp. 918, 934 (Ill., I949).

23 The rule that the author of a trust has the right to determine the onlylegal method in which a vacancy in the trusteeship may be filled was established in cases involving natural trustees. See French v. Northern Trust Co., I97 Ill. 30, 38, 64 N.E. 105, 107 (1902); Estate of Beckwith v. Cooper, $25^{8}$ Ill. App. 4II, 4 I8 (I930); Equitable Trust Co. v. Fisher, I06 Ill. I89, I95 (I882). There has been no Illinois case in which this rule was applied to a vacancy caused by the consolidation or merger of a corporate trustee. 
The contrary opinion of the court of appeals was also based on testator intent. In holding that the trusteeship was not vacated by the first consolidation, ${ }^{23}$ the court said: "[I]nasmuch as the testator was presumed to know that consolidation might occur, he necessarily contemplated that it would occur and that, when consolidation did occur, he intended what the laws says [sic], name$\mathrm{ly}$, that the functions of the merging corporations would pass to the new corporation." In ruling on the consolidation with First National, the court extended this presumption of knowledge and intent to include the McFadden Act, enacted after the testator's death. This extension exposes the presumption as mere judicial gesturing, which might well have been dispensed with in favor of a clear statement of the policy considerations underlying this sound decision.

\section{STANDING TO ATTACK SPENDTHRIFT TRUST CREATED BY BENEFICIARY}

"Even in jurisdictions in which spendthrift trusts are permitted, the settlor cannot create a spendthrift trust for his own benefit." ' This general precept certainly means that the settlor's creditors ${ }^{2}$ and probably his voluntary alienees ${ }^{3}$ can reach the settlor's interest in such a trust, but it has not been entirely clear whether the settlor himself or another beneficiary ${ }^{4}$ could attack the trust on the theory that it is contrary to public policy. While Professor Bogert does state that such a spendthrift trust "should be subject to attack by the creditors only," 5 most of the other authorities do not specifically mention the settlor or beneficiary in this connection. Moreover, ambiguous statutes have beclouded the issue, ${ }^{6}$ and the question has rarely arisen before the courts. ${ }^{7}$

${ }^{23}$ The court maintained that the appointed trustee lived on in the consolidated corporation, and only died with respect to "formal legal existence." While manipulation of the various aspects of the concept of corporate entity have been a traditional part of the law of this subject, the above exposition would seem to be unavailable in Illinois, where the cases, including the Zinser case, have invariably held the constitutent corporate entities to be dissolved on consolidation. See Scheidel Coil Co. v. Rose, 242 Ill. 484, 90 N.E. 22I (I909); Chicago Title \& Trust Co. v. Doyle, 259 Ill. 489, 102 N.E. $79 \circ$ (I9I3). (r939).

× Scott, Trusts $\S x_{5} 6$ (I939). Such a trust is sometimes said to be "invalid." IIg A.L.R. 35

${ }^{2}$ Mackason's Appeal, 42 Pa. 33० (I862); Rest., Trusts $\S$ I56(e) (I935); I Scott, Trusts $\S$ I56 (1939); I Bogert, Trusts and Trustees $\$ 224$ (1935).

3 Byrnes v. Comm'r, rro F. 2 d 294 (C.C.A. 3 d, I940); City Bank Farmers Trust Co. v. Kennard, I N.Y.S. 2d 369 (1937); Rest., Trusts $\$ 156$ (e) (I935); I Bogert, Trusts and Trustees $\$ 224$, at 734 (I935). Contra: Hackley v. Littell, I5० Mich. I06, IX3 N.W. 787 (I907); see II9 A.L.R. 37 (I935); I38 A.L.R. I323 (I942).

4 Or perhaps the settlor himself in his capacity as a beneficiary.

5 I Bogert, Trusts and Trustees $\S 224$, at 734 (1935).

${ }^{6}$ See text at note $I 7$ infra.

7 Perhaps this is because few settlors ever thought they could succeed in getting the courts to allow them to attack the trust for an invalidity which the settlors themselves created. 